\title{
Correspondence
}

\section{Do We Know What We Do not Know? A Response to Celine Bonnet}

\author{
Isabelle Moncarey, Sofie Van den Abeele, Ignaas Devisch ${ }^{\star}$
}

Artevelde University College, University of Ghent, Belgium

Received: 1 November 2013, Accepted: 13 November 2013, ePublished: 16 November 2013

$\mathrm{F}$ ood taxes increase prices of food or food ingredients in order to stimulate consumers to change their eating behaviour and finally to level up population health. Their aim is to tackle the high rates of obesity and other lifestyle diseases. As Bonnet argues, often food taxes are set up out of an economic perspective (1). To change consumer behaviour is one thing, to level up people's health is a complex matter. Evidently, to evaluate the most accurate measures, governments require rigorous consideration (2). People have to go along a process, through different stages and challenges (3-6).

In 'Food taxes: a new holy grail?', we start from the questions 'Will it work?' and 'Do we want it?' (7). But even prior to that, we also need to demarcate the borders of 'unhealthy food'. Overall, as stated by Bonnet (8), sweet drinks, junk food, savoury and sweet biscuits are considered as 'unhealthy products', Lobstein and Davies propose 'nutrient profiling' (9); nevertheless today, there is no consensus on what is unhealthy food. As a consequence, European countries like France, Hungary and Denmark, implement food taxes to decrease the consumption of unhealthy food, but each of them taxes different ingredients. At least this is confusing. Do we have to increase our consumption of fat, or sugar, or salt? And how is this related to physical activity?

Many questions remain. As Bonnet underpinned, food taxes tend to be effective, but do their positive effects counterweigh the negative ones $(10,11)$ ? Food taxes have the most unpredictable and negative consequences; they are regressive, their social and cultural value is not pondered, for they undermine freedom in lifestyle choice; not to speak of their unpredictable economical consequences (11-13).

If food taxes are supposed to be effective when it comes down to health, we need to rely upon evidence-based arguments from a medical, political and economical point of view $(5,12,14)$. To stipulate only one aspect; many studies are based upon outcome variables different from health, e.g. consciousness, behaviour (2); an effect on behaviour may differ from a health effect (1517).

Next to that, also public acceptation of food taxes is crucial in this. In a democratic society, it is important to involve people in decisions (18), in order to convince people. Food taxes should be part of a global health strategy (19); if not, they are doomed to fail or people will only look after substitutes which may even be more unhealthy.

Sometimes it is good to know what we do not know.
Ethical issues

Not applicable.

\section{Competing interests}

The authors declare that they have no competing interests.

\section{Authors' Contributions}

SVA and IM wrote a first version of this paper; ID revised this version and added the last two paragraphs; SVA and IM wrote a second version; ID revised and edited the final version.

\section{References}

1. Kim D, Kwachi I. Food taxation and pricing strategies to "Thin Out" the obesity epidemic. Am J Prev Med 2006; 30: 430-7.

2. Capacci S, Mazzocchi M, Shankar B, Macias JB, Verbeke W, Pérez-Cueto FJ, et al. Policies to promote healthy eating in Europe: a structured review of policies and their effectiveness. Nutr Rev 2012; 70: 188-200.

3. Carson T, Hidalgo B, Ard J, Affuso O. Dietary Interventions and Quality of Life: A systematic Review of the Literature. J Nutr Educ Behav 2013; S1499-4046 (13) 00629-5.

4. McKenzie S, Harris M. Understanding the relationship between stress, distress and healthy lifestyle behaviour: a qualitative study of patients and general practitioners. BMC Fam Pract 2013; 14: 166.

5. Traill WB, Shankar B, Verbeke W, Hoefkens C, Mazzocchi M, Capacci $S$, et al. Effectiveness of policy interventions to promote healthy eating and recommendations for future actions: evidence form the eatwell project [internet]. 2013. Available from: http:// eatwellproject.eu/en/upload/Reports/Deliverable\%205_1.pdf

6. Yaniv G, Rosin O, Tobol Y. Junk-food, home cooking, physical activity and obesity: The effect of the fat tax and the thin subsidy. $J$ Public Econ 2009; 93: 823-30.

7. Devisch I. Food taxes: a new holy grail? International Journal of Health Policy and Management 2013; 1: 95-7.

8. Bonnet C. How to set up an effective food tax? Comment on "Food taxes: a new holy grail?" International Journal of Health Policy and Management 2013; 1: 233-4.

9. Lobstein T, Davies S. Defining and labelling 'healthy' and 'unhealthy' food. Public Health Nutr 2009; 12: 331-40.

10. Food Ethics Council. Fat taxes: can taxing unhealthy food and drink improve health? Report of the Business Forum meeting [online]. 2012. Available from: http://www.foodethicscouncil.org/system/ files/Business_Forum_report_120522\%20-\%20final.pdf

11. Traill WB. Economic perspectives on nutrition policy evaluation. Journal of Agricultural Economics 2012; 63: 505-27.

12. Faulkner GE, Grootendorst P, Nguyen VH, Andreyeva T, ArbourNicitopoulos K, Auld MC, et al. Economic instruments for obesity

${ }^{\star}$ Corresponding author: Ignaas Devisch; Email: Ignaas.Devisch@Ugent.be 
prevention: results of a scoping review and modified delphi survey. Int J Behav Nutr Phys Act 2011; 8: 109.

13. ten Have M, de Beaufort ID, Teixeira PJ, Mackenbach JP, van der Heide $A$. Ethics and prevention of overweight and obesity: an inventory. Obes Rev 2011; 12: 669-79.

14. Strnad J. Conceptualizing the "fat tax": The role of food taxes in developed economies [internet]. 2005. Available from: http://papers. ssrn.com/sol3/papers.cfm?abstract_id $=561321$

15. Eyles H, Ni Mhurchu C, Nghiem N, Blakely T. Food pricing strategies, population diets, and non-communicable disease: a systematic review of simulation studies. PLoS Med 2012; 9: e1001353.
16. Tiffin $\mathrm{R}$, Arnoult $\mathrm{M}$. The public health impacts of a fat tax. Eur $\mathrm{J}$ Clin Nutr 2011; 65: 427-33.

17. Thow AM, Jan S, Leeder S, Swinburn B. The effect of fiscal policy on diet, obesity and chronic disease: a systematic review. Bull World Health Organ 2010; 8: 609-14.

18. Leicester A, Windmeijer F. The 'fat tax': economic incentives to reduce obesity [internet]. 2004. Available from: http://www.ifs.org. uk/publications/1797

19. Franck C, Grandi SM, Eisenberg MJ. Taxing Junk Food to Counter Obesity. Am J Public Health 2013; 103: 1949-53. 